\title{
CHARACTERIZATION AND PARTICIPATIVE MAPPING OF NON-TIMBER FOREST PRODUCT EXTRACTION: THE CASE OF LEATHERLEAF FERN Rumohra adiantiformis (G. FORST.) CHING
}

\author{
CARACTERIZAÇÃO E MAPEAMENTO PARTICIPATIVO DA EXTRAÇÃO DE PRODUTO FLORESTAL NÃO- \\ MADEREIRO: O CASO DA SAMAMBAIA Rumohra adiantiformis (G. FORST.) CHING
}

\author{
Mel Simionato MARQUES ${ }^{1,2^{*}}$; Natalia HANAZAKI ${ }^{2}$
}

Submitted at 12/04/2016; Accept at 09/08/2016; Published at 19/09/2016

\begin{abstract}
Non-timber forest products (NTFP) comprehend plant products other than wood and firewood originating from natural or managed vegetation types. Rumohra adiantiformis (G. Forst.) Ching is one of these NTFP, a fern commercialized all around the world. The extractive activity of the species was characterized in the region of the Acaraí State Park, at São Francisco do Sul, Santa Catarina, Brazil. The extraction of the fern for commercial purposes generates income and helps in securing the livelihoods of families in the Acaraí region. The fern is harvested year round by a small number of extractivists in areas within and surrounding the Acaraí State Park. The harvesting activity in the region is dynamic, shaped by factors such as the low amount paid to the harvesters, as well as the relationships between them, and other complementary activities that generate income. The local knowledge about the species and its harvesting was registered. Participatory mapping supplemented the information gathered in the interviews, creating a spatial perspective of this NTFP harvesting. There is a potential to promote actions for sustainability of the fern harvesting, including the conservation goal.
\end{abstract}

KEYWORDS: NTFP, fern extraction, protected areas, restinga

\section{RESUMO}

Produtos Florestais Não-Madeireiros (PFNM) compreendem produtos vegetais que não a madeira e a lenha, oriundos de formações vegetais naturais ou manejadas. Rumohra adiantiformis (G. Forst.) Ching é um desses PFNM comercializado no mundo inteiro. A atividade extrativista desta espécie foi caracterizada na região do Parque Estadual Acaraí, em São Francisco do Sul, Santa Catarina, Brasil. A extração da samambaia com finalidade comercial gera renda e auxilia a segurança dos modos de vida de famílias na região do Acaraí. A samambaia é coletada ao longo do ano por um pequeno número de extrativistas em áreas do Parque Estadual Acaraí e seu entorno. A atividade extrativista é dinâmica, influenciada por fatores como o baixo valor pago aos coletores, assim como as relações entre eles e outras atividades complementares que geram renda. $O$ conhecimento local sobre a espécie e o extrativismo foi registrado. $O$ mapeamento participativo complementou as informações levantadas nas entrevistas, criando uma perspectiva espacial do extrativismo desse PFNM. Há um potencial de promover ações para a sustentabilidade da extração de samambaia, incluindo o objetivo de conservação.

PALAVRAS-CHAVE: PFNM, extração de samambaia, áreas protegidas, restinga

\footnotetext{
${ }^{1}$ Post-Graduation Program in Plant Biology, Federal University of Santa Catarina, Florianópolis, Brazil. *melsimimar@gmail.com

2 Laboratory of Human Ecology and Ethnobotany, Ecology and Zoology Department, Federal University of Santa Catarina, ECZ-CCB-UFSC, Florianópolis, SC 88010-970, Brazil.nnatalia.hanazaki@ufsc.br
} 


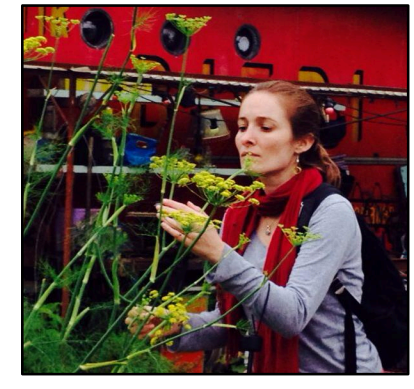

${ }^{1,2}$ Mel Simionato Marques is a Biologist and M.Sc. in Plant Biology graduated UFSC.She focused her research in Ethnobotany, knowledge and use of plant resources. Bilingual teacher for children, with an Environmental Education approach.

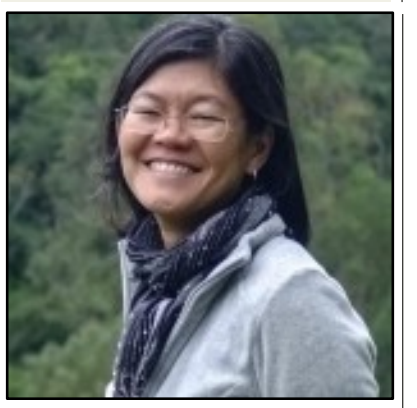

Natalia Hanazaki is an Ecologist graduated at UNESP, M.Sc. in Ecology (USP) and Ph.D. in Ecology (UNICAMP). Professor of Ecology, Ethnobotany, Ethnoecology and Human Ecology at UFSC since 2002. Areas of expertise: local use of resources and its implications for biodiversity conservation and traditional knowledge enhancement as a tool for biodiversity conservation and local development.

\section{INTRODUCTION}

The definition of Non-Timber Forest Products (NTFP) is not consensual, but we can consider NTFP as plant products other than wood and firewood originated from natural or managed vegetation types that can provide services such as watershed, carbon sequestration, tourism and other forest services and benefits (NEUMANN and HIRSCH, 2000; BELCHER, 2003; SHAANKER et al., 2004; TICKTIN, 2004). Several authors discuss ecological, economic and social aspects of the extraction of different NTFP worldwide, approaching and sometimes questioning the sustainability of this extractive activity (SHAANKER et al., 2004; FERNANDEZ et al., 2012; JALILOVA et al., 2012; SAHA and SUNDRIYAL, 2012; BRUKAS et al., 2013; ZENTENO et al., 2013).

Among NTFPs we can mention edible fruits (SCHROTH et al., 2004), medicinal resources such as oleoresin (NEWTON et al., 2012), building materials such as palm leaves (SVENNING and MACÍA, 2002) and others with multiple uses (FADIMAN, 2008). In Brazilian Atlantic coastal areas the main extracted NTFPs are ornamental plants such as the leatherleaf fern Rumohra adiantiformis (G. Forst.) Ching (CONTE et al., 2000; HANAZAKI et al., 2007), bromeliads and orchids (NEGRELLE et al. 2012) and bryophytes of the genus Sphagnum (RANCURA et al., 2010; HANAZAKI et al., 2007). Rumohra adiantiformis is a fern of the Dryopteridaceae family, also known as black fern or seven-weeks fern (COELHO-DE-SOUZA et al., 2006). This species has a pantropical distribution and is also found in temperate regions of the southern hemisphere, occurring in South America, Central America, Australia, Asia, South Africa and some islands in the Indian Ocean (GELDENHUYS and VAN DER MERWE, 1994). It occurs in different ecosystems, including rocky formations, forests in different successional stages and sandbanks (MILTON and MOLL, 1988; COELHO-DE-SOUZA et al., 2008).

The fern is a NTFP marketed worldwide and began to gain greater commercial visibility in the 1960s in European, Japanese and American markets (COELHO-DE-SOUZA et al., 2008). The marketed product is the green leaf, which is used for making floral arrangements. The preference of this species for such purpose is due to the durability of the leaves after harvesting (MILTON and MOLL, 1988). Most of the fern marketed worldwide comes from cultivated areas in Florida and Costa Rica; however, in areas where the populations of this species are abundant the fern is harvested from the nature, such as in Brazil and South Africa (MILTON, 1987; MILTON and MOLL, 1988; COELHO-DE-SOUZA et al., 2006). More than half of the volume commercialized in Brazil is harvested in the state of Rio Grande do Sul (COELHO-DE-SOUZA et al., 2006), yet the harvesting was also recorded in other parts of the Atlantic coast, especially in sandbank areas (or restinga 
vegetation) of Brazilian Southeastern region (CONTE et al., 2000; HANAZAKI et al., 2007).

In Brazil, fern harvesting was studied in the state of Rio Grande do Sul (BALDAUF et al., 2007; BALDAUF and REIS, 2010), which contributed to the legal regulation of this activity in a state level (RIO GRANDE DO SUL, 2006). In the state of São Paulo, in Ilha Comprida, researches about the fern extraction helped in defining local policies for harvesting (CONTE et al., 2000; OLIVEIRA, 2002). For other regions of the Brazilian coast where the species is harvested, there is still a lack of information about such activity. Aiming to fill one of these gaps, the objective of this study is to characterize and map the harvesting of the fern Rumohra adiantiformis at Acaraí region (São Francisco do Sul, Santa Catarina), through a participatory approach. In this region the fern harvesting started from the 1970s, and emerged as an alternative livelihood for some local families (FOPPA and MEDEIROS, 2011).

\section{METHODOLOGY}

Study area

The study area is located on the north coast of the state of Santa Catarina, in the municipality of São Francisco do Sul (26 $6^{\circ} 4^{\prime} 36^{\prime \prime S}$, $\left.48^{\circ} 38^{\prime} 17^{\prime \prime} \mathrm{W}\right)$. The area comprises a protected area called Acaraí State Park, which was established in the eastern portion of the island of São Francisco with an area of 6638.00 hectares (SANTA CATARINA, 2005) (Figure 1). This region has two distinct vegetation types: coastal vegetation (mangroves and pioneer formations of marine influence in sandy soils, or restingas) and Atlantic rainforest (lowland Quaternary tropical rain forest) (KLEIN, 1978).

The area is inserted in the temperate climatic zone, humid and with no dry season (NIMER, 1979), with predominance of humid mesothermal climate with hot summer (Cfa),

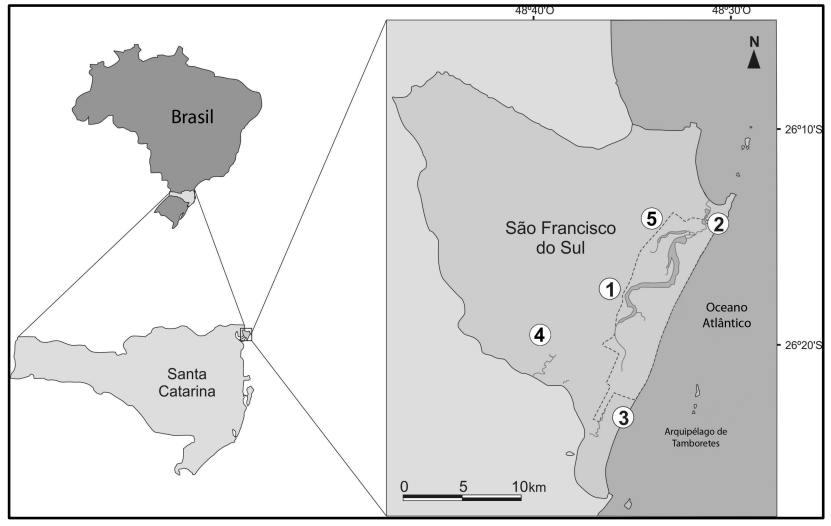

Figure 1: The municipality of São Francisco do Sul, Santa Catarina (Brazil). The dotted line corresponds to the Acaraí State Park. Communities: 1) Tapera; 2) Praia Grande; 3) Ervino; 4) Miranda; 5) Capivaru.

according to the Köppen classification, and rainfall is well distributed throughout the year (STCP, 2009). The annual average temperature is $20.6^{\circ} \mathrm{C}$, with rainy season from January to March; total annual rainfall is $1847.68 \mathrm{~mm}$, with the driest month in May with monthly rainfall of $41 \mathrm{~mm}$ (STCP, 2009).

According to the last official data from IBGE (2010), the total population of São Francisco do Sul is 42,520 inhabitants. There are three communities adjacent to Acaraí State Park: Tapera, Praia Grande and Ervino (Figure 1). Tapera (or São José do Acaraí) is situated beside the Acaraí River and in the countryside of São Francisco do Sul island, with a high proportion of native residents. Praia Grande and Ervino are newer urbanized neighbourhoods, located by the sea, with several houses used for summer tourism season. People from other two communities (Miranda and Capivaru) also use the area. São Francisco do Sul has the 5th largest harbor in the country, which generates $70 \%$ of the municipality income. Tourism and commerce are also important for the local economy. There is no data about the relevance of NTFP harvesting in the socioeconomic context. 


\section{Collecting and analyzing data}

We identified the harvesters during a previous study about the general use of plant resources in the area (MARQUES, 2013). We asked them to indicate other harvesters, allowing us to reach all the active people working in fern harvesting in the region during the study period.

Previously to data collection we explained the objectives of the work and obtained the authorization of all the participants for the research. This research was authorized by Ethics Committee of Research with Human Beings of Universidade Federal de Santa Catarina (protocol 2157/2011). After obtaining informed consent from each participant we did semi-structured interviews based on Baldauf (2006). These interviews were recorded, transcribed and analyzed qualitatively. The interviews addressed questions about the origin of the families of harvesters and the history of this activity in the region, as well as about the characteristics of the harvesting itself. We monitored the harvesting trips with prior authorization and according to the availability of each harvester.

Participatory mappings (based on $D E$ BOEF and THIJSSEN, 2007; GERHARDINGER et al., 2010; MARTINS, 2012) were conducted to complement the information gathered in the interviews; also allowing us to put the information from the interviews in a spatial perspective. For participatory mapping we used $40.0 \mathrm{~cm} \times 27.5 \mathrm{~cm}$ printed aerial images of the region (obtained from Google Earth Pro software). The harvesters indicated over the maps the areas of harvesting, describing the main characteristics of each area. The dialogues during the mapping sessions were recorded with the permission of the participants. All field work was done between August 2011 and July 2012.

\section{RESULTS AND DISCUSSION}

We did five interviews involving eight harvesters from five different families (two couples, one father with his daughter, one harverster who worked alone and another one who worked for one of the couples), given the familiar nature of the activity to some of the groups. These people represent the total fixed fern harvesters in the region who agreed to participate in the study. They were men and women from different cities in Santa Catarina state. Ages varied from 32 to 68 years old. Other four harvesters were not available or did not agree to participate in this research. Eight harvesters did the participatory mapping, in three different workshops. Additionally, one harvester did the participatory mapping alone with the interviewer.

We identified four fixed groups of harvesters, locally called samambaieiros: two from Tapera, one from Miranda and one from Ervino (Figure 1). Two of these groups are formed only by members of the family of the main person identified as a harvester. One harvester exerts this activity alone and the other case involved a family but eventually integrates more people from the community. There is no community-based organization (such as association or cooperative) nor frequent communication between the groups of harvesters, featuring the independent work of each group, even in cases where the fern is sold to the same buyer. The fern extraction is performed just for a few people probably because the economic return is not attractive, especially for the harvesters. The middleman is the one who really benefits from this productive chain. In the past, harvesters in that region used to collect other NTFPs such as 
straw, but the demand for this resource decreased and for the fern increased.

Fern harvesting is a dynamic activity, practiced to supplement the income for three of the families interviewed. Only for two families (with more than one harvester working in this activity) this was their main economic activity. Families that do not have the fern harvesting as their only activity complement their income with retirement wages, small businesses, small-scale fishing and diarist services. Other people from elsewhere (especially from nearby cities) occasionally use the same areas to harvest fern, but there is no record or register to control this practice, and they were not considered fixed harvesters.

We did not find a diversification of harvesting practices, possibly due to the small number of extractors. Baldauf et al. (2007) observed different typologies of harvesters in Maquiné (Rio Grande do Sul State, Brazil), in an area where around 3000 families had their livelihoods related to fern harvesting. In São Francisco do Sul, there is no combination of fern harvesting and farming, as described for Rio Grande do Sul (RIBAS and MIGUEL, 2004; COELHO-DE-SOUZA et al., 2006; BALDAUF et al., 2007). All the groups in São Francisco do Sul harvest in third-party lands, and not in their own land or leased areas, and they have no strong links to farming. However, even being few families directly involved with fern harvesting as a fixed activity, these groups depend upon the area of the State Park and adjacencies. The harvesters are among the few local families who keep their livelihood activities directly dependent on local resources, maintaining the practices of previous generations who lived from fishing and harvesting of NTFPs. The fern extraction seems to be established in the 1970s as a complimentary activity for the families in the region of Acaraí (FOPPA and MEDEIROS, 2011).

Local knowledge about Rumohra adiantiformis According to the harvesters, the fern sprouting occurs throughout the year, but it is intensified in the summer (between December and March), and is reduced in winter (June to August). The highest average rainfall in the region is concentrated between January and March, being January the month with the highest averages (230.1 to $250 \mathrm{~mm}$ ) (CIRAM/EPAGRI, 2012). For Coelho-de-Souza et al. (2006) the number of sprouts decreases in autumn and increases in early spring, thus, the plant growth is mostly influenced by high temperatures combined with the rain. The local knowledge of harvesters from São Francisco do Sul agrees with literature, considering that they identify the hot, rainy season (as in summer) as important for sprouting. Rain and temperature were also identified by Baldauf and Reis (2010) as the main factor influencing the emergence and development of shoots, yet they also considered the influence of the phases of the moon, which was not mentioned in São Francisco do Sul.

Harvesters distinguished between 'sun leaves' and 'shade leaves' when considering different types of resources harvested. The leaves of plants exposed to the sun are smaller and thicker, while the leaves of plants growing in shaded environments are larger, thinner and more delicate (therefore more fragile when handling). The preference for the 'sun leaves' is related to the greater resistance of these in relation to the shadow ones. The stems also have different thicknesses: the sun leaf stem is thicker, while the shadow leaf has a thinner stem.

Another harvesters' preference is the absence of fern sori (clusters of sporangia). 
When the leaves have recent sori, with greenish or yellowish color, they are collected as well as the leaves with no sori. However, when the sori are darker in color, they are less harvested, to avoid the complaints from the buyers. That happens because when there are dark sori in the ferns, the flower shops avoid buying them because they have to take the sori out for aesthetic reasons.

All extractors mentioned the importance of taking care of the sprouts, not to trample them and break them, since they will grow and ensure the presence of the resource to be extracted in the future. Baldauf et al. (2007) described the trampling in areas with fern as a management practice immediately after extracting, in order to stimulate growth of new leaves.

In the discourse of the harvesters there is a joint idea of the NTFP collecting and of the conservation of the species. They considered that the more the fern is removed, the more it will 'gain strength' to grow, but according to some interviewees they should wait at least two months before going back to collect the fern at the same area. According to all interviewees, the idea of sustainability of the fern harvesting was present, and it was considered as an action similar to pruning, which 'strengthens the growth' of the plant. Moreover, in all the interviews the issue of the care taken with ferns appeared, avoiding the trampling and avoiding the collection of too young leaves. Meanwhile, the demands of the buyer appear as defining the amount and the frequency of extraction, especially at particular times, such as Mothers' day (May), Valentines' day (June) and Memorial Day (November). We assume that these factors can affect the structure and dynamics of populations of fern, once the market demands do not necessarily follow the life cycle of the species. However, the relationship between market demands and sustainability was not mentioned by the harvesters.

The interest in the contribution of NTFPs as a strategy for maintaining livelihoods and as a source of income for rural households is increasing, but this potential remains limited and open to questioning (ADAM et al., 2013). Some authors discuss the role of NTFP harvesting as to reconcile environmental conservation and socioeconomic development strategy (SVENNING and MACÍA, 2002; SHAANKER et al., 2004; SAHA and SUNDRIYAL, 2012). Other authors have questioned whether development and income generation are compatible with environmental conservation (ARNOLD and PEREZ, 2001; FERNANDEZ et al., 2012). According Ticktin et al. (2002) the impacts of NTFP collection depend on local patterns of resource extraction. In São Francisco do Sul and the case of the leatherleaf fern at Acaraí Park area there could be a search for the balance between environmental conservation and income generation for the families. Considering the small amount of groups harvesting the fern and the relatively large extraction area, the environmental agency and the harvesters could work in a participative manner to ensure the sustainability of the activity in long term. Researches about the dynamic of fern population and others would be welcome to that initiative.

Milton (1987) examined the effect of extraction of four species in South Africa, among them $R$. adiantiformis, and Milton and Moll (1988) discussed the effect of the harvesting of this fern leaf. They monitored experimentally the areas where the species was harvested for commercialization, and showed that the sustainability of the activity depends on the intensity of extraction. Milton (1987) 
stated that it is not recommended to harvest more than once a year from the same area, since few leaves are produced per year by rhizome (2 to 4), and that the leaves grow smaller than the former harvested leaves. Baldauf and Reis (2010) showed that for some management systems used in the northern coast of Rio Grande do Sul, fern collecting may prove sustainable in view of the rapid regeneration of leaves and the absence of differences between managed and nonmanaged populations in terms of proportion of sprouts and young leaves. The climatic differences between Rio Grande do Sul (Brazil) and South Africa can explain these contrasting results related to the influence of harvesting in the size of the leaves, especially due to the highest rainfall in Brazil, which was identified as the main factor influencing the emergence and development of sprouts (BALDAUF and REIS, 2010).

\section{Extraction areas}

The harvesting of Rumohra adiantiformis occurs in a wide area of Acaraí region that includes parts of the State Park (Figure 2). The main area where fern is harvested is a $17 \mathrm{~km}$ long stretch of restinga nearby the sea, in the frontal dunes and in areas of bushes and trees. Fern is also harvested in private areas, in the understory of Pinus sp. and Eucalyptus sp. Fern is harvested from both sunny exposed areas and in the shaded forest areas (both native and reforestation).

According to the harvesters, the factors that determine their preference for collection sites is the distance from their homes, coupled with access to the areas, the quality of fern leaves collected, the time it takes for the fern sprouting after collection, and environmental characteristics of the sites. Therefore, the preferred sites and criteria for collection could be summarized in: the closer to home and more accessible (criteria: distance and easiness); the more open and exposed to sun environments, by having more resistant ferns compared to shaded sites (criteria: quality of the extracted leaves).

Areas with reforestation with Pinus sp. and Eucalyptus sp. (Figure 2, areas 4, 5 and 6) were indicated as areas accessed in very sunny days, because of the shadow in the understory. The drawback concerns the lower quality of the leaves, when compared with 'sun leaves'.

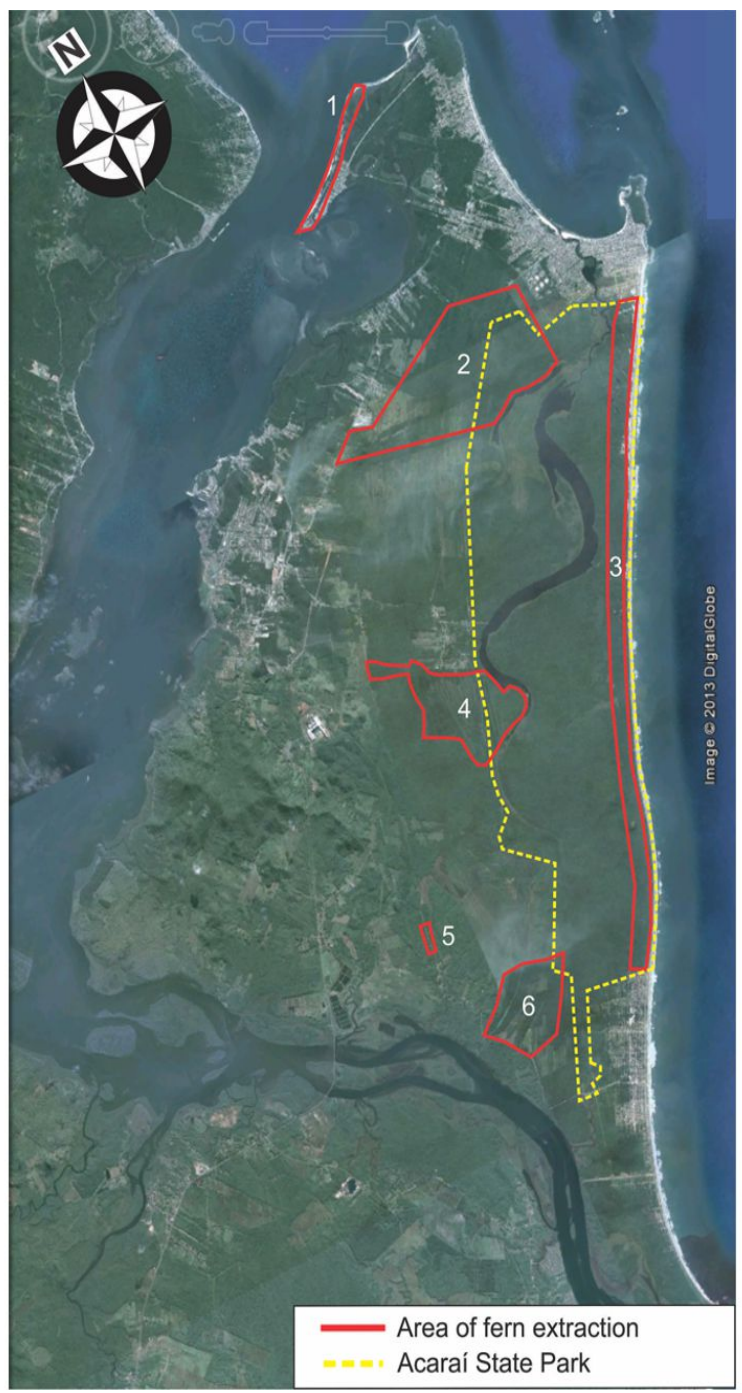

Figure 2: Synthesis of the participatory mappings for areas of fern harvest (red lines) and the delimitation of Acaraí State Park (yellow dotted line), São Francisco do Sul, Brazil. 1) Capri (swampy mangrove); 2) malha do capeta (or devil's mesh); leirinha (or small mount), sapatão (or big shoe) and casqueirinho (no translation); 3) sandbank accompanying road linking Ervino to Praia Grande; 4, 5 and 6) reforestation areas with Pinus sp. and Eucalyptus sp. 
Another disadvantage is the Pinus dry needles, which often fall on the ferns making the harvesting process more time consuming because it can hurt the hands of the harvesters when they are collecting the ferns.

One spot was mentioned in all mappings as the worst site because it is a swampy mangrove environment (Figure 2, area 1). According to the harvesters, the highest quality fern - and therefore preferred - is from the area of Acaraí State Park, which corresponds to a range of sandbank accompanying the road linking Ervino to Praia Grande (Figure 2, area 3). The leaves harvested in this area are those called 'sun leaves', being smaller, tougher and with a little darker color than the 'shadow leaves'.

In area 2 there are close spots with different characteristics, defining diverse preferences. Some spots were preferred due to the amount and quality of the fern leaves, as malha do capeta (or devil's mesh) and leirinha (or small mount) (Figure 2, close spots in area 2). In area 2 also, other spots sapatão (or big shoe) and casqueirinho (no translation) were not prioritized in the choice of areas for collection, the first being a waterlogged place, and the second for not having enough leaves for more than one person at a time to harvest.

During the interviews, the harvesters mentioned the respect each group had towards the other groups of harvesters, regarding the access of some areas, creating an informal spatial division between them.

However, the mapping showed the overlap of collection sites indicated by different groups of harvesters, suggesting some competition for the resources. In the practice, they prefer to harvest in spots where they usually go (calling it 'their' areas), but with the scarcity of the resource they resort to 'others' areas' too.
The location and boundaries of Acaraí State Park are unclear for the harvesters. Two groups of harvesters indicated the Park in the mapping workshops, showing overlapping areas with spots accessed for plant collection, yet with disagreements over the boundaries of the Park, indicating potential sources of conflict with the Park objectives. Since the Park establishment was a slow and complex process due to legal issues when the data were collected, the relationship between harvesters and Park managers was not stable and was being built by that time.

The areas identified during the participatory mapping constitute a web of possibilities to harvesters that allows the rotation of spots, since although there are preferences; the collection is maintained even in non-preferred spots, allowing a pause for the fern growth and regeneration of the individuals.

Although we were careful to previously discuss the mapping with the harvesters in order to clarify the spatial language used and to ensure the understanding of this participatory tool (as recommended by GERHARDINGER et al., 2010), we still observed some difficulties. The first was related to the scale, which could be circumvented with ease after a few minutes watching the images and indicating some landmarks, such as the main road and the Babitonga bay. Another challenge was to make the participants comfortable handling the materials (such as pens and aerial images). Some areas were mentioned by the harvesters (e.g. as 'native forest'), but they could not specify the contour of these areas. This imprecision could be related both to their difficulties when handling the materials and analyzing the images, but also because these areas are not priorities for fern harvesting, and thus they are rarely accessed. 


\section{Fern harvesting and marketing}

Fern harvesting appears to have started between the decades of 1970 and 1980. One harvester (62 years old) reported that the first middleman to seek his family to buy fern, used to sell it to flower shops in the city of Curitiba (about $170 \mathrm{~km}$ far): "Then he used to buy in Araquari, Rainha, Barra Velha, he bought all around. Then after he stopped [...] other buyers began to appear [...]. I work with a firm from São Paulo, Santo André [...] and it is going for 30 years." (Interview 2)

The fern harvesting is a very dynamic activity, with many variations in the size and composition of groups of harvesters. Most of them sell their production to middlemen, but one harvester also acts as a first middleman in the supply chain.

The middlemen usually go once a week to get the fern, which is separated into malas (or bags) or pacotes (or packages). Each bag contains between 40 and 70 fern leaves. This variation is due to the varying size and thickness of the leaves and their petioles, which determine the final volume of the bag. The firmer and thicker leaves and petioles, the lower the number of leaves required to achieve the volume of a bag.

The amount paid for the harvester per bag varies from $R \$ 1.00$ to $R \$ 1.20$ (about USD 0.45 to USD 0.54 , in 27/04/2014), depending on the middleman. The harvester who works as a first middleman pays $\mathrm{R} \$ 0.70$ (USD 0.31) per bag for people who assist him in the harvesting. There were reports of dissatisfaction with this latter middleman, given the difference in the value paid for the harvester. These relationships between the harvesters and between them and the middlemen also shape the unstable dynamics of this group. Such disagreements can result in splitting groups of harvesters in smaller groups, and even in some people deciding to abandon the activity temporarily, searching for other sources of income such as artisanal fishing. By the other hand, other people can join the group of harvesters for short periods of time.

This scenario depicts the dynamics of the fern harvesting activity in the region. While for some harvesters it is a matter of survival, with a high dependence of this activity, for others it is an income to supplement to other activities, such as artisanal fishing, day laborer work, petty trade or other sources of income, such as retirement.

This also reflects the instability and the uncertainty of the harvesters' labor, which depends on the market demands and the relationships between the harvesters themselves. The low price paid to the harvesters and high dependence on these middlemen was previously reported in other studies developed in Rio Grande do Sul (GERHARDT, 2002; KUBO, 2005; COELHO-DESOUZA et al., 2006; SUÁREZ, 2007). Larsen and Olsen (2007) reviewed 119 references on trade of medicinal plants in Nepal and one of the hypotheses tested was that the middlemen paid low prices to the harvesters, with an unfair profiting. For 37 references this hypothesis was present, and in just five the middlemen were not considered exploitative, by providing services that would not be available otherwise (LARSEN and OLSEN 2007). Jensen (2009) analyzed the supply chains of products from agar wood plants (Aquilaria spp.) in the Republic of Laos and, in contrast, did not confirm the involvement of intermediaries in the supply chain, in an atypical situation in studies on NTFPs.

At São Francisco do Sul, the harvesters did not know the amount paid to the other actors in the production chain, but reported 
that the middleman is who profits with the fern sales. On the other hand, middlemen play a key role in the production chain, doing a service that the harvesters could hardly run by logistical difficulties, such as transportation to buyers. In Sudan, Adam et al. (2013) analyzed the production chain of NTFPs and argued that the harvesters of these products would have more bargaining power if the chain was transparent, where each level knew the values received by others. Furthermore, Adam et al. (2013) concluded that the government commitment and efforts are also needed to rebuild and strengthen local institutions for natural resource management.

However, in Rio Grande do Sul, Gerhardt (2002) pointed out that the maintenance of the activity is related to the fact that the harvesters have as first priority to ensure their families' livelihood, which makes this unbalanced profit essential to them, even in conditions of low financial returns and high dependence on middlemen. The same can be said about the reality of extractors from São Francisco do Sul that maintain the activity of fern harvesting as a survival strategy, even with low dividend yield and not always constant. Additionally, Gerhardt (2002) interpreted people keeping this activity to pursue common goals, such as their permanence in the area, the maintenance of family structure and kinship and mutual aid.

Fern harvesting legalization and prospects for the future

According to the law $11.428 / 2006$, the collection of forest products such as fruits, leaves or seeds is free, since they do not jeopardize the species of fauna and flora, and observing the specific legal limitations, especially concerning access to genetic resources, and to associated traditional knowledge (BRASIL, 2006). In addition to that, according to the Decree $6.660 / 2008$, exploring forest products such as leaves, fruits and seeds with commercial purposes depends on authorization by the competent environmental agency. State law of Santa Catarina (Law $10.472 / 1997)$ also opens space for the legality of any extraction of native forest products, under certain conditions, such as prior authorization from the state environmental agency, and 'after finding sustainability for the species to be extracted through a simplified stock inventory prepared by a qualified professional' (SANTA CATARINA, 1997). Furthermore, transportation, processing, use and consumption should be exclusively on the properties or possessions of traditional populations. However, fern harvesting in Santa Catarina has not been regularized so far, and more studies are needed to assure the sustainability of the activity in order to advance in the legalization in Santa Catarina. Negrelle et al. (2014) mention a similar legal situation for Sphagnum harvesting in Paraná.

In addition to the limitations imposed by Brazilian environmental legislation for harvesting activities in areas of the Atlantic Forest Biome, there are still major restrictions imposed by the national system of protected areas (BRASIL, 2002), related to activities in full protection areas. A Park is a category of protected area with full protection, in which the direct use of resources is not allowed (BRASIL, 2000, 2002). The restrictions imposed by this type of protected area are unclear to the harvesters, who have the general perspective that the implementation of the Park will represent no restrictions for the maintenance of the activity in that region. It is worth to notice that the Acaraí State Park was created in 2005 and since then it is being implemented. To accommodate these 
contradictions, a Statement of Commitment and Adjustment of Conduct was proposed in 2012, which would allow the registration of families whose livelihoods depend on artisanal fishing and fern harvesting, and will enable the fern harvesting for the next 20 years.

When questioned about the legalization of the fern harvesting, the interviewees showed different perspectives. There is no clarity among the interviewees of the illegality of the activity, except for one harvester. There was also some confusion related to the process of legalization and the production of a membership card that would be an authorization to maintain harvesting. The harvester that acknowledged the activity as illegal considered that if he had a large enough area to plant the fern, legalization would be positive. But in another case, he feels indifferent. Another harvester considered the advantage of the legalization of the activity in order to confer greater security against the risks to which they are exposed when working at the woods.

Even with the Adjustment of Conduct or with a possible legalization of the fern harvesting, Foppa and Medeiros (2011) had pointed out the possibility of abandonment of this activity due to high dependence on middlemen and the low value paid for the harvesters. One of the interviewees stated that "(...) only has a future in fern who sells out there. Because here we have no future" (Interview 1).

The prospect of the activity decreasing or becoming extinct over time was also perceived by other harvesters, associated with a reduction in the demand or with seeking other alternatives for younger generations: “(...) the sale will end, I think. Because artificial flowers took over (...) it will decrease (...). It will be greatly reduced. Even for us here it greatly diminished. And each time it decreases. Did not I just say here that I am working less?" (Interview 4), and "(...) it is something that the children will not want for them. So who wants to have a good job, needs to study" (Interview $5)$.

One of the harvesters mentioned the importance of the Park as a measure to preserve the environment and, consequently, the fern. He was comparing the Park to the reforestation company, which operates around the Park, and through planting Pinus and Eucaliptus and using chemical inputs, causes the death of the ferns.

For the northern coast of Rio Grande do Sul, there was a process of community organization and articulation, accompanied by scientific research on the species and on the harvesting activity (COELHO-DE-SOUZA et al., 2008), which culminated in the regulation of activity in that state (RIO GRANDE DO SUL, 2006). In the region of São Francisco do Sul the reality is different: there is no strong community organization on the fern harvesting yet, and research on the topic is recent. Moreover, as already mentioned, only one of the respondents know about the illegality of fern harvesting.

Another case worth mentioning is from south coast of São Paulo state, in Ilha Comprida municipality (OLIVEIRA, 2002). In this area the community based organization related to fern harvesting was originally done by the local municipality, concurrently with the scientific study of fern harvesting. After the survey to map how many families depended on the extraction of fern as an income supplement, the municipality offered a course on and helped the harvesters to organize the activity, sectoring the municipality in five areas. The harvesters were organized between the established areas, which had two 
representatives each. Since April 1999 the community based organization was created and in June 2000 a license for the commercialization was created, legalizing the sales in the municipality. According to Oliveira (2002), the legalization in this municipality reduced in $80 \%$ the illegal removal of ferns and prevented against the middlemen from other regions. The sales were exclusively for the municipality, which was in charge of the distribution and marketing of the fern. The extraction was allowed for periods of 10 months, with two months for the closure (January and February). However, this paternalistic relationship was broken due to the production, considered low by municipality, which had made a commitment to a major buyer. According to Oliveira (2002), the problems faced in Iha Comprida originated in how the relationships were established, with a vertical posture being maintained by the municipal government. Through this experience we observe the importance of working in a participatory manner with NTFP harvesters to look for solutions concerning their livelihoods and conservation goals.

\section{CONCLUSIONS}

Participatory mapping allowed spatializing the information gathered in the interviews, as well as to access information that had not previously arisen. This type of method is interesting to be combined with information from the interviews, even with the difficulties and limitations inherent to it. It is clear the confusion regarding the boundaries of the protected area, which is a crucial element in the discussion of legalization of the activity.

The harvesting of Rumohra adiantiformis in São Francisco do Sul, as most NTFP, is strongly dependent on the demands of the market, which can bring vulnerability to the species and the environments in which it is harvested. However, it should be considered that the fern harvesters built skills and expertise along the time, knowing about its life cycle and having practices which favor the recruitment, such as protecting the sprouts, young leaves and avoiding mature reproductive leaves. The small number of people who practice the activity can also be considered a positive aspect in terms of the sustainability of the resource in the region. Therefore, the potential exists to develop actions for sustainability of the fern harvesting. This is already present in the discourse of the harvesters, and it can contribute to management actions including conservation goals. Local practices can be both positive and negative for fern sustainability and should be considered with caution. Some practices can strengthen the leaves, and careful measures such as avoiding trampling the seedlings can be positive in the long term. However, we must consider that there are several non-fixed harvesters who do not necessarily adopt these practices.

Another important point to be noted is the lack of a community based organization of the harvesters. This hampers some processes, such as sharing knowledge and practices among people depending on this activity for their livelihoods, and accessing areas in common. With some degree of collective organization some actions can be more feasible, such as the rotation of harvesting areas and to mobilizing the group for claiming their own rights. Furthermore, the exchange of experiences between harvesters and the development of research and extension would be facilitated.

To confirm the sustainability of fern harvesting, further studies of population structure and dynamics, with continued followup, are needed. Baldauf and Reis (2010, p. 157) 
considered that "the demographic structure of leatherleaf fern is strongly influenced by climatic factors and the forest succession process, which suggests the need for continued monitoring over several years". However, such studies must take into consideration the environmental heterogeneity of the area and the difficulty of identifying and allocating plots in areas where no extraction occurs, but where the species is present. Finally, it should also be considered that the dynamic characteristics of the activity, with the participation of harvesters from different neighborhoods and even from the urban area, complicate the control and access to the resource.

\section{ACKNOWLEDGEMENTS}

Thanks to the families involved for their collaboration to this work. Thanks to B.Vieira and E.M.Nakamura for the elaboration of figure 1, to H.S.N.Liporacci and A.R.S.Lopes for helping with figure 2. This paper is the contribution number $\quad 10$ supported by CAPES/PNADB through the project 'Knowledge, use and conservation of plant biodiversity in Atlantic Forest and Caatinga' (UFSC/UFRPE/UFRGS). N.Hanazaki thanks to CNPq for a research productivity scholarship (306895/2009-9 and 309613/2015-9).

\section{REFERENCES}

ADAM, Y.O.; PRETZSCH, J.; PETTENELLA, D. Contribution of non-timber forest products livelihood strategies to rural development in drylands of Sudan: Potentials and failures. Agricultural Systems, v. 117, n. C, p. 90-97, 2013.

ARNOLD, J.E.M.; PÉREZ, M.R. Can non-timber forest products match tropical forest conservation and development objectives? Ecological Economics, v. 39, n. 3, p. 437-447, 2001.

BALDAUF, C. Extrativismo de samambaia-preta (Rumohra adiantiformis (G. Forst.) Ching) no Rio Grande do Sul: Fundamentos para o manejo e monitoramento da atividade. 2006. $247 \mathrm{f}$. Thesis (M.Sc. in Plant Biology). Federal University of Santa Catarina, Florianópolis.

BALDAUF, C.; HANAZAKI, N.; REIS, M.S. Caracterização etnobotânica dos sistemas de manejo de samambaia-preta (Rumohra adiantiformis (G. Forst) Ching - Dryopteridaceae) utilizados no sul do Brasil. Acta Botanica Brasilica, v. 21, n. 4, p. 823-834, 2007.

BALDAUF, C.; REIS, M.S. Effects of harvesting on population structure of leatherleaf fern (Rumohra adiantiformis (G. Forst.) Ching) in Brazilian Atlantic Rainforest. American Fern Journal, v. 100, n. 3, p. 148-158, 2010.

BELCHER, B.M. What isn't an NTFP? International Forestry Review, v. 5, n. 2, p. 161168, 2003.

BRASIL. Law No. 9.985, 18 July 2000. <http://www.planalto.gov.br/ccivil_03/Leis/L9985.h tm>. Accessed on September $25^{\text {th }}, 2012$.

BRASIL. Federal Decree No. 4340, 22 August 2002.

<http://www.planalto.gov.br/ccivil_03/decreto/200 2/d4340.htm>. Accessed on September 25 $5^{\text {th }}, 2012$.

BRASIL. Law No. 11.428, 22 December 2006. <http://www.planalto.gov.br/ccivil_03/_ato20042006/2006/lei/l11428.htm>. Accessed on September $25^{\text {th }}, 2012$.

BRUKAS, V.; FELTON, A.; LINDBLAH, M.; SALLNAS, O. Linking forest management, policy and biodiversity indicators: A comparison of Lithuania and Southern Sweden. Forest Ecology and Management, v. 291, p. 181-189, 2013.

CIRAM-EPAGRI (Centro de Informações de Recursos Ambientais e de Hidrometeorologia de Santa Catarina). <http://ciram.epagri.sc.gov.br>. Accessed on October 18 $8^{\text {th }}, 2012$.

COELHO-DE-SOUZA, G.; KUBO, R.R.; GUIMARÃES, L.; ELISABETSKY, E. An ethnobiological 
assessment of Rumohra adiantiformis (samambaiapreta) extractivism in Southern Brazil. Biodiversity and Conservation, v. 15, p. 2737-2746, 2006.

COELHO-DE-SOUZA, G.; PEREIRA, F.M.D.; KUBO, R.R. Contextualização da problemática ambiental com ênfase nos aspectos jurídicos. In: COELHO-DESOUZA, G.; KUBO, R.R.; MIGUEL, L.A. (Eds.). O extrativismo da samambaia-preta no Rio Grande do Sul. Porto Alegre: Editora da UFRGS, 2008. p. 17-37.

CONTE, R.; REIS, M.S.; RIBEIRO, R.J. Estudo de parâmetros técnicos para o manejo sustentado da samambaia-silvestre (Rumohra adiantiformis). In: DIEGUES, A.C.; VIANA, V.M. (Eds.). Comunidades tradicionais e manejo dos recursos naturais da Mata Atlântica. São Paulo: Provográfica, 2000. p. 29-42.

DE BOEF, W.S.; THIJSSEN, M.H. Ferramentas participativas no trabalho com cultivos, variedades e sementes: Um guia para profissionais que trabalham com abordagens participativas no manejo da agrobiodiversidade no melhoramento de cultivos e no desenvolvimento do setor de sementes. Wageningen: Wageningen International, 2007. $87 \mathrm{p}$.

FADIMAN, M.G. Use of Mocora, Astrocaryum standlevanum (Arecaceae), by three ethnic groups in Ecuador: Differences, similarities and market potential. Journal of Ethnobiology, v. 28, p. 92-109, 2008.

FERNANDEZ, F.A.S.; ANTUNES, P.C.; MACEDO, L.; ZUCCO, C.A. How sustainable is the use of natural resources in Brazil? Natureza \& Conservação, v. 10, n. 1, p. 77-82, 2012.

FOPPA, C.C.; MEDEIROS, R.P. Nosso Acaraí: Dinâmica socioecológica e relações territoriais das populações tradicionais da área de entorno do Rio Acaraí, município de São Francisco (SC). Technical report for the Public Civil Action No. 061.07.009145T6. State Public Ministery/FATMA. Itajaí: UNIVALI. 2011.

GERHARDINGER, L.C.; GODOY, E.A.; DAPPER, C.G.; CAMPOS, R.; MARCHIORO, G.B.; SFORZA, R. et al. Mapeamento participativo da paisagem marinha no Brasil - experiências e perspectivas. In: ALBUQUERQUE, U.P.; LUCENA, R.F.P.; CUNHA, L.V.F.C. (Eds.). Métodos e técnicas na pesquisa etnobiológica e etnoecológica. Recife: NUPEEA, 2010. p. 107-149.

GELDENHUYS, C.J.; VAN DER MERWE, C.J. Site relations and performance of Rumohra adiantiformis in the southern Cape forests. Report
FOR-DEA, Division of Forest Science and Technology. Pretoria: CSIR. 1994.

GERHARDT, C.H. Agricultores familiares, mediadores sociais e meio ambiente: A construção da "problemática ambiental" em agro-ecosistemas. 2002. 524 f. Thesis (M.Sc. in Rural Development). Federal University of Rio Grande do Sul, Porto Alegre.

HANAZAKI, N.; CASTRO, F.; OLIVEIRA, V.G.; PERONI, N. Between the sea and the land: The livelihood of estuarine people in southeastern Brazil. Ambiente e Sociedade, v. X, n. 1, p. 121-136, 2007.

IBGE (Instituto Brasileiro de Geografia e Estatística). 2010. Demographic census. <http://cidades.ibge.gov.br/xtras/home.php >. Accessed on October $18^{\text {th }}, 2012$.

JALILOVA, G.; KHADKA C.; VACIK, H. Developing criteria and indicators for evaluating sustainable forest management: A case study in Kyrgyzstan. Forest Policy and Economics, v. 21, p. 32-43, 2012.

JENSEN, A. Valuation of non-timber forest products value chains. Forest Policy and Economics, v. 11, p. 34-41, 2009.

KLEIN, R.M. Flora ilustrada catarinense: Mapa fitogeográfico do Estado de Santa Catarina, V Parte - mapa fitogeográfico. Itajaí: Herbário Barbosa Rodrigues, 1978. 24p.

KUBO, R.R. Coletores de samambaia-preta e a questão ambiental: Estudo antropológico na área dos fundos da Solidão, município de Maquiné, encosta Atlântica no Rio Grande do Sul. 2005. 240 f. Dissertation (Ph.D. in Social Antropology). Federal University of Rio Grande do Sul, Porto Alegre.

LARSEN, H.O; OLSEN, C.S. Unsustainable collection and unfair trade? Uncovering and assessing assumptions regarding Central Himalayan medicinal plant conservation. Biodiversity Conservation, v. 16, p. 1679-1697, 2007.

MARQUES, M.S. Pessoas e plantas no entorno de unidade de conservação de proteção integral: 0 caso do Parque Estadual Acaraí, São Francisco do Sul, litoral norte de SC. 2013. 149 f. Thesis (M.Sc. in Plant Biology). Federal University of Santa Catarina, Florianópolis.

MARTINS, I.M. Conhecimento Ecológico de pescadores artesanais sobre peixes de interesse comercial: Contribuições para o manejo e conservação na Baía de Tijucas, SC. 2012. 116 f. Thesis (M.Sc. in Ecology). Federal University of Santa Catarina, Florianópolis. 
MILTON, S.J. Effects of harvesting on four species of forest ferns in South Africa. Biological Conservation, v. 41, p. 133-146, 1987.

MILTON, S.J.; MOLL, E.J. Effects of harvesting on frond production of Rumohra adiantiformis (Pteridofita: Aspidiaceae) in South Africa. Journal of Applied Ecology, v. 25, p. 725-743, 1988.

NEGRELLE, R.R.B.; BORDIGNON, S.E.; FERREIRA, M.R.; SAMPAIO, L.K. Extrativismo e comercialização de Sphagnum (veludo): características, implicações, socioeconômicas e ecológicas e perspectivas. Revista Brasileira de Horticultura Ornamental, v. 20, n. 1, p. 53-66, 2014.

NEGRELLE, R.R.B.; MITCHELL, D.; ANACLETO, A. Bromeliad ornamental species: Conservation issues and challenges related to commercialization. Acta Scientiarum, v. 31, n. 1, p. 91-100, 2012.

NEUMANN, R.P.; HIRSCH, E. Commercialisation of non-timber forest products: Review and analysis of research. Bogor: Center for International Forestry Research. 2000.

NEWTON, P.; WATKINSON, A.R.; PERES, C.A. Spatial, temporal, and economic constraints to the commercial extraction of a non-timber forest product: Copaíba (Copaifera spp.) oleoresin in Amazonian reserves. Economic Botany, v. 66, n. 2, p. 165-177, 2012.

NIMER, E. Um modelo metodológico de classificação de climas. Revista Brasileira de Geografia, v. 41, n. 4, p. 59-89, 1979.

OLIVEIRA, V.G. Educação ambiental e manejo de recursos naturais em área de proteção ambiental: - caso dos extratores de samambaias da Ilha Comprida - São Paulo. 2002. 104 f. Thesis (M.Sc. in Forest Resources). University of São Paulo, Piracicaba.

RANCURA, S.; RIBEIRO, M.M.; NORDI, N. Considerações sobre a coleta de Sphagnum no município de Cananéia, estado de São Paulo, Brasil. Acta Botanica Brasilica, v. 24, n. 2, p. 328-334, 2010.

RIBAS, R.P.; Miguel, L.A. Extração e comercialização de folhagens ornamentais da Mata Atlântica: O caso da verdes (Rumohra adiantiformis) no RS. Revista de Economia e Sociologia Rural, v. 42, p. 4, 575-596, 2004.

RIO GRANDE DO SUL. Normative Instruction 001, 21 November 2006. Oficial Diary of Rio Grande do Sul State.
SAHA, D.; SUNDRIYAL, R.C. Utilization of nontimber forest products in humid tropics: Implications for management and livelihood. Forest Policy and Economics, v. 14, n. 1, p. 28-40, 2012.

SANTA CATARINA. Decree No. 3517, 23 September 2005. http://www.fatma.sc.gov.br/index.php?option=com _content\&task=view\&id=84\&Itemid=160. Accessed on March 29 2012.

SANTA CATARINA. Law No. 10472, 12 August 1997.

<http://200.192.66.20/ALESC/PesquisaDocumentos .asp>. Accessed on September $23^{\text {rd }}, 2012$.

SCHROTH, G.; MOTA, M.S.S.; LOPES, R.; FREITAS, A.F. Extractive use, management and in situ domestication of a weedy palm, Astrocaryum tucuma, in the central Amazon. Forest Ecology and Management, v. 202, n. 1/3, p. 161-179, 2004.

SHAANKER, R.U.; GANESHAIAH, K.N.; NAGESWARA RAO, N.A. Ecological consequences of forest use: From genes to ecosystem - a case study in the Biligiri Rangaswamy temple wildlife sanctuary, South India. Conservation \& Society, v. 2, n. 2, p. 347-363, 2004.

STCP ENGENHARIA DE PROJETOS LTDA. Plano de manejo do Parque Estadual Acaraí - Plano Básico Volume I/III. Curitiba. 2009.

SUÁREZ, J.E.A. O extrativismo de samamabaiapreta: Uma alternativa de renda para agricultores familiares da encosta da Mata Atlântica no município de Maquiné. 2007. 197 f. Thesis (M.Sc. in Rural Development). Federal University of Rio Grande do Sul, Porto Alegre.

SVENNING, J.; MACÍA ,M.J. Extraction of Geonoma macrostachis Mart. leaves for thatch: An exploration of sustainability. Forest Ecology and Management, v. 167, p. 251-262, 2002.

TICKTIN, T. The ecological implications of harvesting non-timber forest products. Journal of Applied Ecology, v. 41, p. 11-21, 2004.

TICKTIN, T.; NANTEL, P.; RAMIREZ, F.; HOHNSL, T. Effects of variation on harvest limits for nontimber forest species in Mexico. Conservation Biology, v. 16, n. 3, p. 691-705, 2002.

ZENTENO, M.; ZUIDEMA P.A.; JONG, W.; BOOT, R.G.A. Livelihood strategies and forest dependence: New insights from Bolivian forest communities. Forest Policy and Economics, v. 26, p. 12-21, 2013. 